\title{
Evaluation of litter material and ventilation systems in poultry production: III. litter reuse, darkling beetle populations and intestinal parasites
}

\author{
Valéria Maria Nascimento Abreu ${ }^{1}$, Doralice Pedroso de Paiva ${ }^{1}$, Paulo Giovanni de Abreu ${ }^{1}$, \\ Arlei Coldebella ${ }^{1}$
}

${ }^{1}$ Embrapa Suínos e Aves, Br 153, Km 110, Caixa Postal 21, 89700-000, Concórdia, Santa Catarina, Brasil.

ABSTRACT - It was evaluated the quality of rice husks or soybean straw as litter substrate and the effect of litter reuse for four consecutive flocks of broiler chickens on populations of darkling beetle and intestinal parasite and as organic fertilizer. The experiment was carried out in four $12 \mathrm{~m} \times 10 \mathrm{~m}$ poultry houses, internally divided in 4 boxes/poultry house with 200 birds/pen for four consecutive flocks, each flock with a duration of 42 days and with a 15-day downtime between flocks. The evaluated treatments were two ventilation systems (stationary or oscillating fans) and two litter materials (soybean straw or rice husks). Darkling beetle population was followed by collecting the insects in traps, three traps per box, and endoparasite litter contamination was determined by eggs/oocyst counts per gram of litter. Levels of dry matter, total nitrogen, total phosphorus, potassium, copper, zinc, manganese, iron, organic carbon and $\mathrm{pH}$ were evaluated by physical/chemical analyses of samples of the litters in each flock. Overall, litters of broilers used by three flocks meet the minimal legal requirements to be marketed as simple organic fertilizer, regardless to the material used as substrate. Soybean straw presented higher darkling beetle counts in stationary ventilation system as well as in oscillating ventilation system. The probability of rice husks litter present contamination by Eimeria spp oocysts is 18.78 times higher in rice husks than in soybean straw litter when both are submitted to oscillating ventilation, and 1.32 higher when stationary ventilation is used. Litter temperature does not influence significantly levels of contamination by oocysts.

Key Words: broiler chickens, litter temperature, oocysts, organic fertilizer, oscillating ventilation, stationary ventilation

\section{Avaliação de materiais de cama e sistemas de ventilação na criação de aves: III. reutilização, população de cascudinho e parasitos intestinais}

RESUMO - Foram avaliados a qualidade da casca de arroz e palhada de soja como substrato de cama e o efeito da reutilização da cama por quatro lotes de frangos de corte sobre a população de cascudinhos e parasitos intestinais e como adubo orgânico. O experimento foi realizado em quatro aviários de $12 \mathrm{~m} \times 10 \mathrm{~m}$ para frangos de corte, divididos internamente em quatro boxes/aviário, com 200 aves/boxe por quatro lotes consecutivos, cada lote com a duração de 42 dias e com intervalo de vazio sanitário de 15 dias, entre lotes. Os tratamentos avaliados foram dois sistemas de ventilação (fixo e oscilante) e dois tipos de material de cama (palhada de soja e casca de arroz). A população de cascudinhos foi acompanhada coletando-se os insetos em armadilhas, três por boxe, e a contaminação da cama por endoparasitos por contagens de ovos/oocistos por grama de cama. Os níveis de matéria seca, nitrogênio total, fósforo total, potássio, cobre, zinco, manganês, ferro, carbono orgânico e pH foram avaliados por análises físico-químicas de amostras das camas em cada lote. As camas de frango utilizadas por três lotes, em média, se enquadram às exigências mínimas legais para serem comercializadas como fertilizante orgânico simples, independentemente do tipo de material utilizado como substrato. A palhada de soja apresentou maior contagem de cascudinhos, tanto com ventilação fixa quanto com ventilação oscilante. A probabilidade de a cama de casca de arroz apresentar contaminação por oocistos de Eimeria spp. é 18,78 vezes maior que a da palhada de soja quando ambas são submetidas à ventilação oscilante e 1,32 vez maior quando sob ventilação fixa. A temperatura da cama não interfere significativamente nos níveis de contaminação por oocistos.

Palavras-chave: adubo orgânico, frango de corte, oocistos, temperatura da cama, ventilação fixa, ventilação oscilante

\section{Introduction}

The effects of several many materials used as poultry litter substrate on poultry performance have been evaluated.
It was shown that litter made of rice husks not only did not impair performance, but it also reduced foot-pad and breast lesions (Angelo et al., 1997; Benabdeljelil \& Ayachi, 1996; Mizubuti et al., 1994; Mouchrek et al., 1992; Santos et al., 2000; 
Willis et al., 1997; Oliveira \& Carvalho, 2002; Araújo, 2007; Atapattu \& Wickramasinghe, 2007). A study on the use of soybean crop residues as poultry litter did not show any influence of this material on broiler performance or on its agronomic value (Ávila et al., 2008). However, these bedding materials have not been evaluated for evolution of darkling beetle and enteric parasite populations.

Alphitobius diaperinus (darkling beetle) adults and larvae are considered a problem in intensive broiler and turkey production. These beetles replicate in the litter, becoming potential vectors of pathogens and parasites both on site and to the neighboring farms. Those insects have been associated to many pathogenic agents, and there are works which reports that they carry Escherichia coli, Salmonella spp, avian leucosis virus, as well as internal parasites, such as coccidian, avian tapeworms, and helminths (Arends, 1987; Arends, 1991), enterobacteria (Chernaki-Leffer et al., 2002) and Clostridium perfringens (Vittori et al., 2007).

Attempts to control darkling beetles have been made by changing the litter $\mathrm{pH}$ using hydrated lime (Watson et al., 2003) or applying insecticides in the entire poultry house during downtime (Salin et al., 2003) or as a management complement during rearing, with application in specific spots, as suggested by Surgeoner \& Romel (2000).

The continuous contact of birds with the excreta in the litter poses a risk of infection with parasites, and coccidiosis caused by Eimeria spp is one of the most significant diseases in this production system. The evolution of oocyst population may determine the need to change the litter, and an evaluation may aid decision-making regarding this need.

Therefore, the present study was carried out to evaluate the performance of rice husks and soybean crop residues as bedding material and the effect of their reuse by four broiler flocks on darkling beetle and parasite populations, as well as their use as organic fertilizer.

\section{Material and Methods}

The experiment was carried out at the experimental field of Suruvi, which belongs to Embrapa Suínos and Aves, Concórdia, Santa Catarina, Brazil. Four $12 \mathrm{~m} \times 10 \mathrm{~m}$ broiler houses were internally divided in four pens each (total of 16 pen), at a density of 200 birds/pen (28 kg meat $/ \mathrm{m}^{2}$ ), totaling 3,200 birds/flock. Four consecutive flocks were followed up. Each flock was reared to 42 days of age, and an interval between flocks (downtime) of 15 days was applied.

Treatments consisted of two ventilation systems (stationary or oscillating) and two litter materials (soybean straw or rice husks). Rice husks and ventilation system using stationary fans were considered as standards as they are commonly used in broiler production. Fans were activated by a thermostat when the environmental temperature reached $25^{\circ} \mathrm{C}$, and they were equipped with a potentiometer and speed regulator matching the broiler house size. Treatments were distributed as follows: house 1 - stationary ventilation system, pens 2 and 3 with soybean straw; pens 1 and 4 with rice husks; house 2 - oscillating ventilation system, pens 2 and 3 with soybean straw; pens 1 and 4 with rice husks; house 3 - oscillating ventilation system, pens 1 and 4 with soybean straw; pens 2 and 3 with rice husks; house $4-$ stationary ventilation system, pens 1 and 4 with soybean straw; pens 2 and 3 with rice husks. Soybean straw was chopped into approximately 3-cm long particles. Litter was initially $10 \mathrm{~cm}$ high and was reused for four consecutive flocks. Litter quality was evaluated in terms of physicalchemical composition, moisture, and compactness. The development of the population of darkling beetles and the evolution of the number of parasite eggs/oocysts was also observed.

In order to evaluate darkling beetles population, it was used three traps per pen made with $20 \times 5 \mathrm{~cm}$ PVC tubes filled with $20 \times 50 \mathrm{~cm}$ rolled-up corrugated cardboard, totaling 48 traps (Safrit \& Axtell, 1984). Traps were placed under the litter in three sites in each pen: at the center, between the external wall and the first line of feeders, and the other two between the feeders, equally distant from the drinkers. Traps remained in the pens for seven days and were removed after catching of each flock. Traps were then placed in $1.0 \mathrm{~L}$ thick plastic bags, closed with thin plasticcoated wire, and submitted to the laboratory. Alphitobius diaperinus adults and larvae were identified and counted, and the total number of individuals was recorded.

Litter samples were collected to count number of endoparasite eggs/oocysts per gram of litter (epg), and they were also submitted to physical-chemical analysis. Two samples were collected per flock: on the day chicks were housed and after catching. In each pen, 15 litter samples, weighing $50 \mathrm{~g}$ each, were collected on the surface and under the surface of the litter centrally to the feeders, drinkers, and external and internal limits of the pens. In the laboratory, after homogenization, $50 \mathrm{~g}$ aliquots were used for endoparasite counting. The remaining sample was submitted to the physical-chemical laboratorial analyses to determine dry matter, ashes, and phosphorus contents. Phosphorus was colorimetrically determined by the molybdovanadate method (Windham, 1995). Pre-dry matter or moisture was determined at $65^{\circ} \mathrm{C}$. Copper, zinc, calcium, manganese, and iron contents were determined by flame 
atomic absorption spectrometry after nitro-perchloric digestion (SDR/MA, 1998). Nitrogen was determined by the Kjeldahl method. Litter $\mathrm{pH}$ was measured according to the method described by Brasil (2007). Organic carbon was titered after chemical oxidation with sulfochromic solution (Tedesco et al., 1995). Potassium was determined by flame photometry (Brasil, 2007).

Litter temperature was recorded by using an infrared thermometer $\left(\right.$ Raytec $^{\circledR}$ ) in five different spots in each pen (two near the lateral pen wall, two near the central aisle, and at the geometrical center of the pen).

Darkling beetle counts were transformed into $\log (y+1)$ and submitted to analysis of variance using a model which considered the effects of litter material, ventilation, flock, and the interaction among these factors. The GLM procedures of SAS statistical package were used (SAS Institute Inc., 2003).

Parasite egg and oocyst counts were used to characterize the presence of absence of parasite in the pens. Parasite presence was analyzed by logistic regression by considering the effects of litter material, ventilation and flock, using LOGISTIC procedures of SAS statistical package (SAS Institute Inc., 2003).

Litter quality data were analyzed by mixed models for repeated measures, considering the effects of litter material, ventilation, and the interaction between litter material and ventilation (plot), sample sampling and respective interactions (subplot, and period (subplot), and three matrix structures of variance and covariance, using the PROC MIXED procedure of SAS statistical package (SAS Institute Inc., 2003), according to Xavier (2000). The structure used for analysis was chosen based on the lowest value of the Akaike Information Criterion (AIC). The estimation method was that of restricted maximum likelihood.

Table 1 - Chemical composition of rice husks and soybean straw before their utilization as litter and values established in Normative Instruction n. 23

\begin{tabular}{lccc}
\hline & Rice husks & Soybean straw & NI-23 \\
\hline Ashes (\%) & 15.18 & 4.33 & \\
Organic carbon (\%) & 35.13 & 33.33 & $\geq 20$ \\
Copper (\%) & traces & 0.00065 & \\
Iron (mg/kg) & 433.25 & 607.63 & \\
Potassium (\%) & 0.075 & 0.108 & \\
Manganese (mg/kg) & 169.85 & 32.75 & \\
Humidity (\%) & 10.35 & 14.33 & $\leq 30$ \\
Nitrogen (\%) & 0.344 & 0.662 & $\geq 1$ \\
Phosphorus (\%) & 0.056 & 0.092 & \\
pH & 6.56 & 7.60 & a.d.* \\
Zinc (mg/kg) & 11.43 & 14.70 & \\
* a.d. - as declared. & & &
\end{tabular}

\section{Results and Discussion}

According to Oviedo-Rondón (2008), poultry production generates nutrient-rich residues that can be utilized to generate energy or to fertilize crops; however, their application to the soil must follow nutrient management plans in order to prevent environmental impacts.

Considering the composition of rice husks and soybean straws before its utilization and the values established in Normative Instruction n. 23 for simple organic fertilizers (Table 1), both materials are very different, except for organic carbon content, and they do not comply with the recommendations of IN-23 for organic fertilizers. Rice husks humidity and $\mathrm{pH}$ values are different from those described by Coufal et al. (2006), who evaluated the reutilization of rice husks as litter material by 18 broiler flocks and reported 9.4\% humidity, $\mathrm{pH} 7.0,0.47 \%$ nitrogen, $0.03 \%$ phosphorus, and $0.27 \%$ potassium in the beginning of the experiment, that is, composition before utilization.

According to Ávila et al. (2008), considering that plant nutrient requirements vary as a function of cultivar, soil, expected yield, and so on, and exceeding supplied quantities remain in the soil and are susceptible to leaching and percolation, it is essential to balance soil and litter compositions. Based on these considerations, the knowledge on the quality (physical-chemical composition, compactness, and reutilization) of litter materials used as alternative to wood shavings is essential as the disposal of such material is part of good production practices.

Litter quality was evaluated according to chemical element levels and physical parameters. Litter chemical composition parameters were significantly affected $(\mathrm{p}<0.05)$ by litter material, except for humidity and zinc. Sampling affected only ashes and potassium content, whereas period significantly influenced $(\mathrm{p}<0.05)$ all parameters. The interaction litter material $\times$ period $\times$ sampling affected organic carbon, copper, iron, potassium, $\mathrm{pH}$ and zinc (Table 2).

In order to study litter chemical composition, samplings were performed in three different periods, as follows: period 1 -15-day interval (downtime) between removal of flock 1 and housing of flock 2; period 2-15-day interval (downtime) between removal of flock 2 and housing of flock 3; and period 3 -15-day interval (downtime) between removal of flock 3 and housing of flock 4 .

The chemical composition of rice husks and soybean straw after utilization (Table 3; Figure 1) indicates a differentiation pattern of chemical element values. In general, values were high after the removal of flock, and decreased after 15 days of downtime in all studied periods. 
Table 2 - Descriptive probability levels of the F test of litter quality parameters using mixed models for repeated measures

\begin{tabular}{lrrrrrrrrrrr}
\hline Causes of variation & Ash $^{1}$ & $\begin{array}{l}\text { Organic } \\
\text { carbon }\end{array}$ & Copper $^{2}$ & Iron $^{1}$ & Potassium $^{1}$ & Manganese $^{2}$ & Nitrogen $^{1}$ & pH $^{1}$ & Phosphorus $^{3}$ Humidity $^{1}$ & Zinc $^{1}$ \\
\hline Litter & $<0.0001$ & 0.5602 & $<0.0001$ & $<0.0001$ & $<0.0001$ & $<0.0001$ & $<0.0001$ & 0.0071 & 0.0078 & 0.0562 & 0.1231 \\
Ventilation & 0.3440 & 0.5953 & 0.3519 & 0.7541 & 0.4946 & 0.4001 & 0.0755 & 0.6883 & 0.5068 & 0.5180 & 0.3719 \\
Litter $\times$ ventilation & 0.2233 & 0.2706 & 0.4540 & 0.7340 & 0.3304 & 0.2349 & 0.6133 & 0.8314 & 0.8829 & 0.1731 & 0.0145 \\
Sampling & 0.8738 & 0.0252 & $<0.0001$ & 0.0001 & 0.3025 & 0.0376 & $<0.0001$ & $<0.0001$ & $<0.0001$ & $<0.0001$ & $<0.0001$ \\
Litter $\times$ sampling & 0.1347 & 0.0017 & 0.0758 & 0.2992 & 0.3904 & 0.0010 & 0.5198 & 0.5837 & 0.5644 & 0.8237 & 0.0010 \\
Ventilation $\times$ sampling & 0.8993 & 0.9499 & 0.0311 & 0.9280 & 0.5362 & 0.0213 & 0.7218 & 0.5421 & 0.7501 & 0.4565 & 0.5215 \\
Litter $\times$ ventilation $\times$ sampling & 0.7488 & 0.6080 & 0.7506 & 0.8390 & 0.3611 & 0.4484 & 0.4270 & 0.5436 & 0.8474 & 0.0205 & 0.7237 \\
Period & $<0.0001$ & $<0.0001$ & $<0.0001$ & $<0.0001$ & 0.0020 & $<0.0001$ & $<0.0001$ & 0.0030 & $<0.0001$ & $<0.0001$ & $<0.0001$ \\
Litter $\times$ period & 0.0009 & 0.0001 & 0.2002 & $<0.0001$ & $<0.0001$ & 0.0024 & 0.0123 & 0.0274 & 0.3581 & 0.4786 & 0.0828 \\
Sampling $\times$ period & 0.6498 & 0.0022 & $<0.0001$ & $<0.0001$ & $<0.0001$ & 0.0021 & 0.0116 & $<0.0001$ & $<0.0001$ & 0.0132 & $<0.0001$ \\
Ventilation $\times$ period & 0.2661 & 0.2732 & 0.6871 & 0.7212 & 0.4258 & 0.5480 & 0.0107 & 0.9713 & 0.3038 & 0.7846 & 0.7377 \\
Litter $\times$ sampling $\times$ period & 0.4377 & 0.0234 & 0.0005 & 0.0008 & $<0.0001$ & 0.0382 & 0.3305 & 0.0200 & 0.4090 & 0.9370 & 0.0018 \\
Litter $\times$ ventilation $\times$ period & 0.0620 & 0.5058 & 0.7772 & 0.0007 & 0.8294 & 0.3003 & 0.5653 & 0.5779 & 0.6013 & 0.5584 & 0.0738 \\
Ventilation $\times$ sampling $\times$ period & 0.8743 & 0.8297 & 0.6515 & 0.7889 & 0.0781 & 0.1419 & 0.5074 & 0.8395 & 0.2193 & 0.3496 & 0.8624 \\
\hline
\end{tabular}

Direct product matrices were used between a non-structured matrix and another matrix: ${ }^{1}$ no structure; ${ }^{2}$ composed symmetry, and ${ }^{3}$ self-regressive of the first order.

Table 3 - Chemical composition of broiler litter made of rice husks or soybean straw

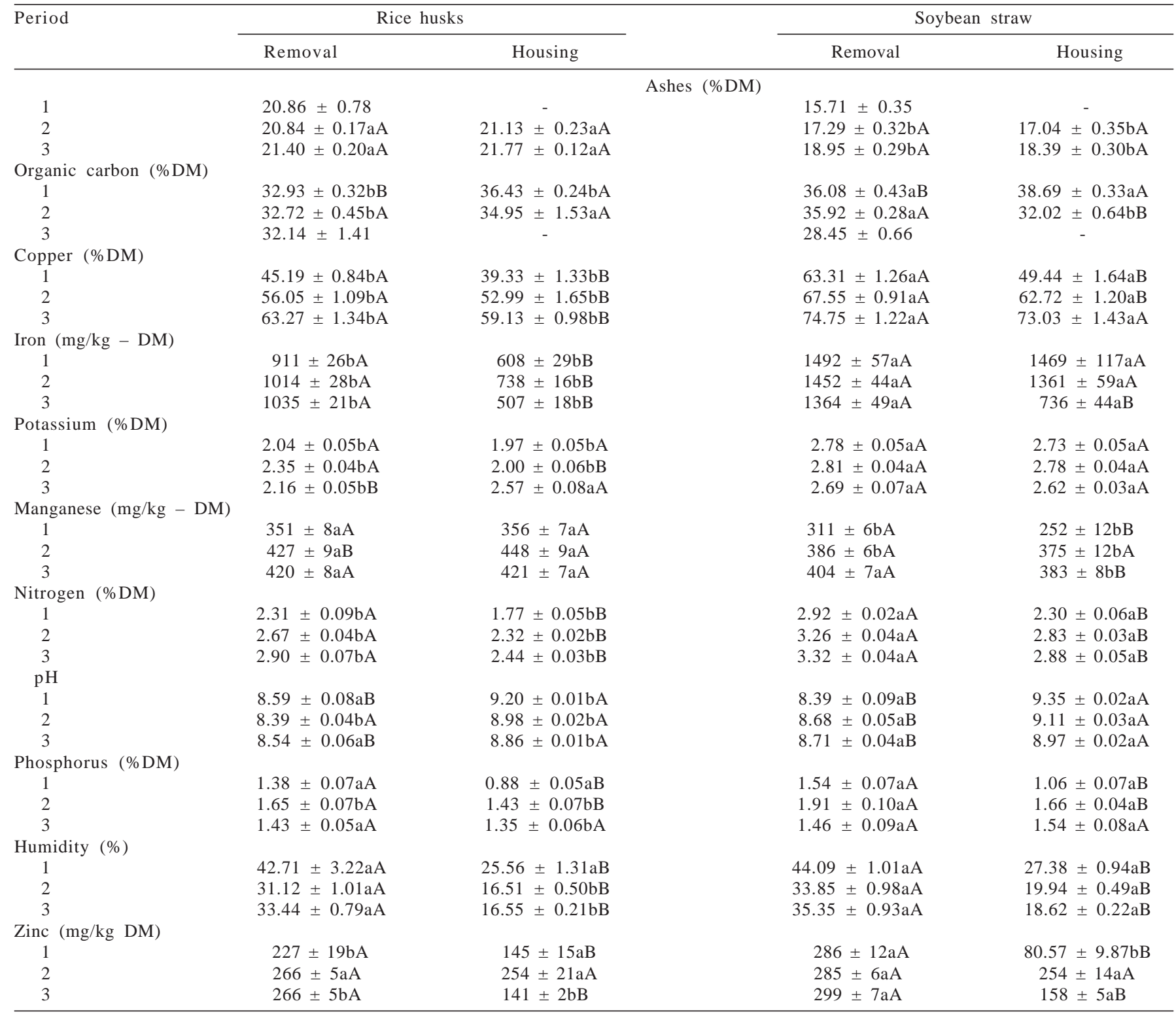

Means followed by different lowercase letters in the same row are different within sampling $(\mathrm{p}<0.05)$ by the $\mathrm{F}$ test.

Means followed by different capital letters in the same columns are different within litter material $(\mathrm{p}<0.05)$ by the $\mathrm{F}$ test. 
a)

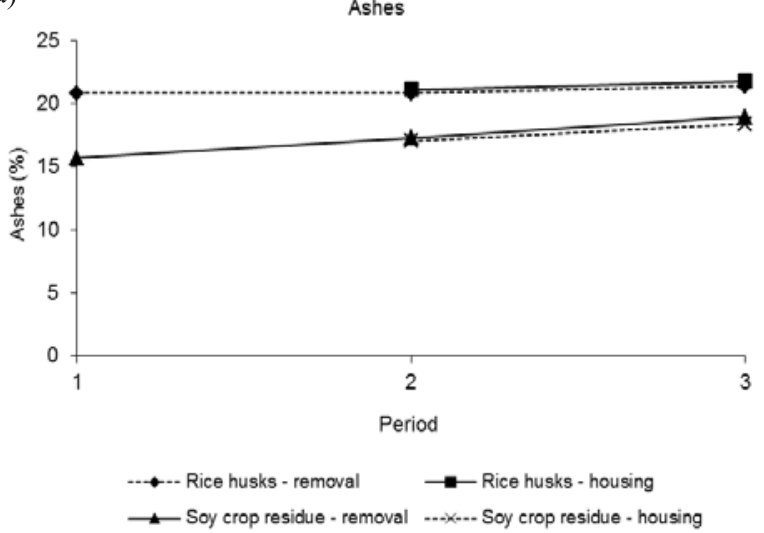

c)

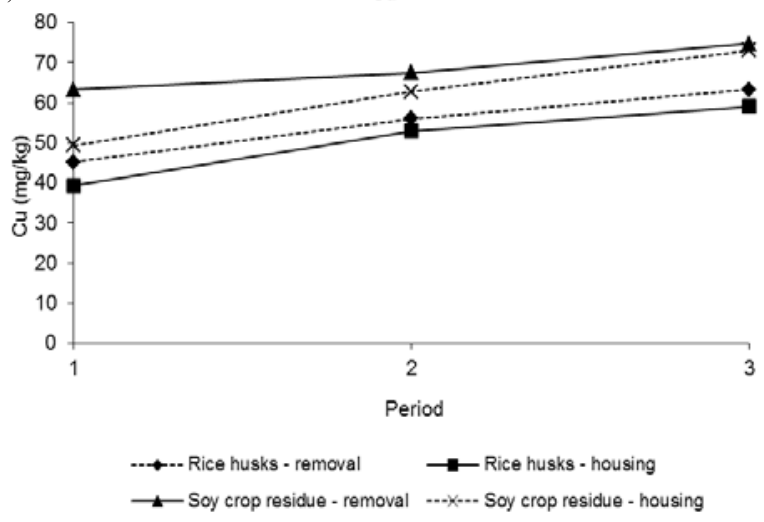

e)

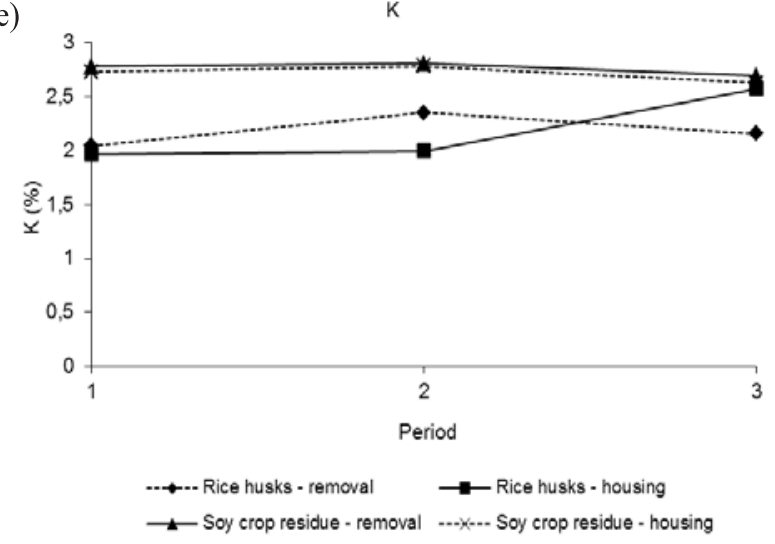

g)

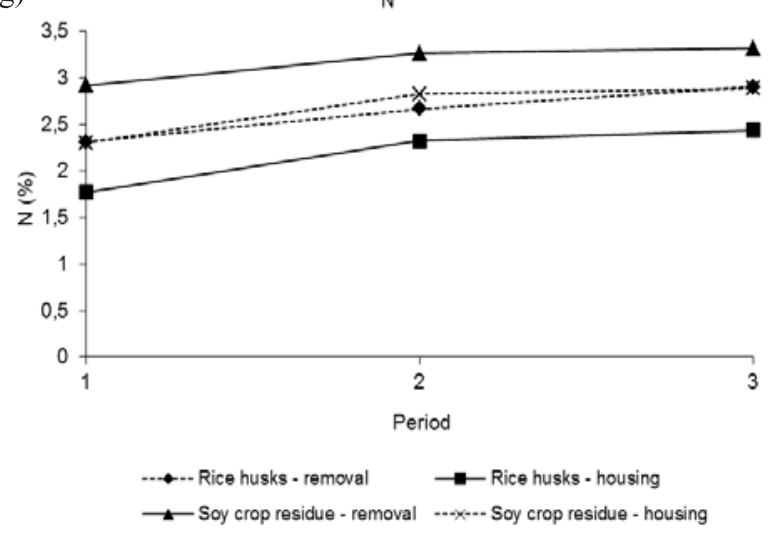

b)

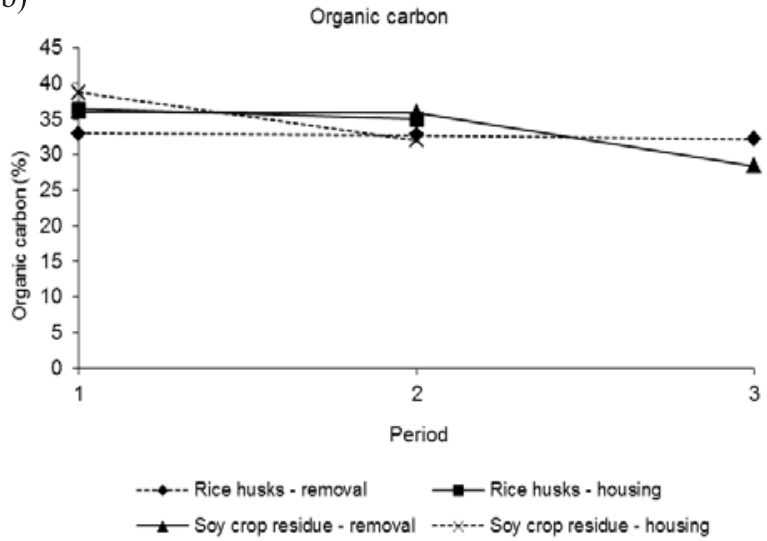

d)

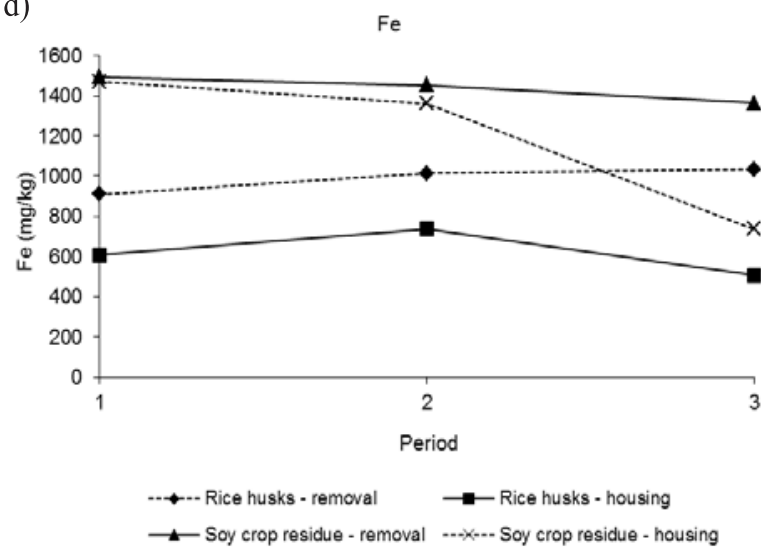

f)

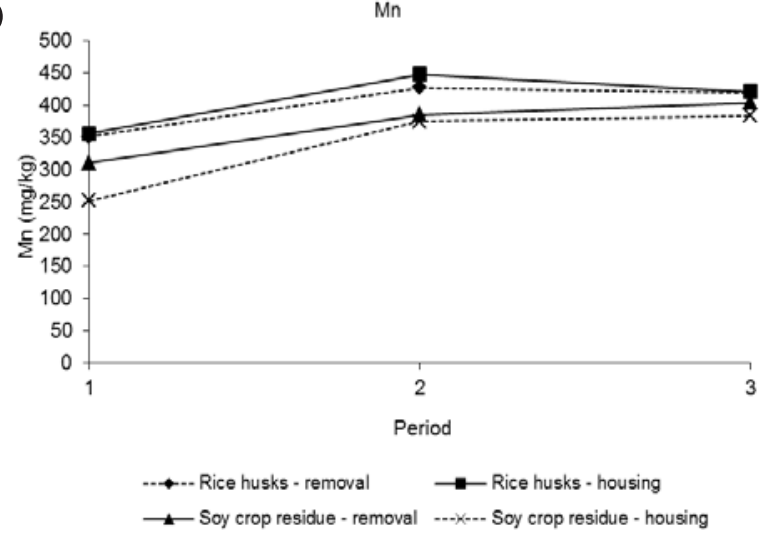

h)

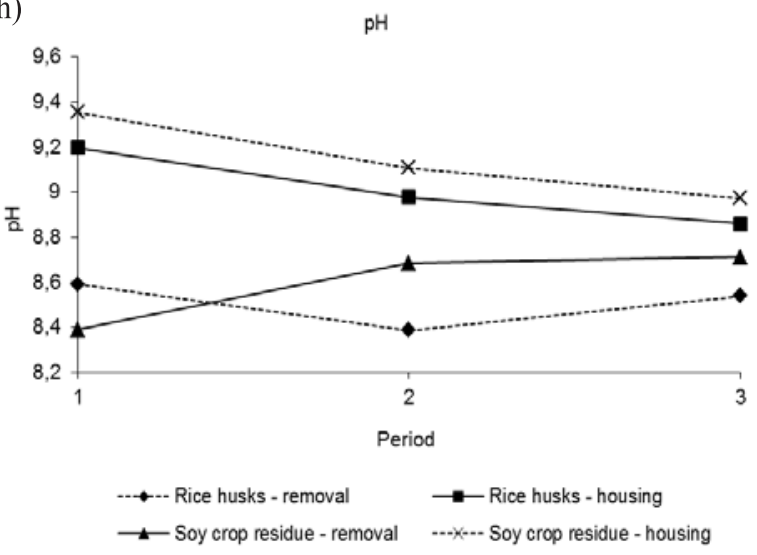

Figure 1 - Continue... 
Cont. Figure 1

i)

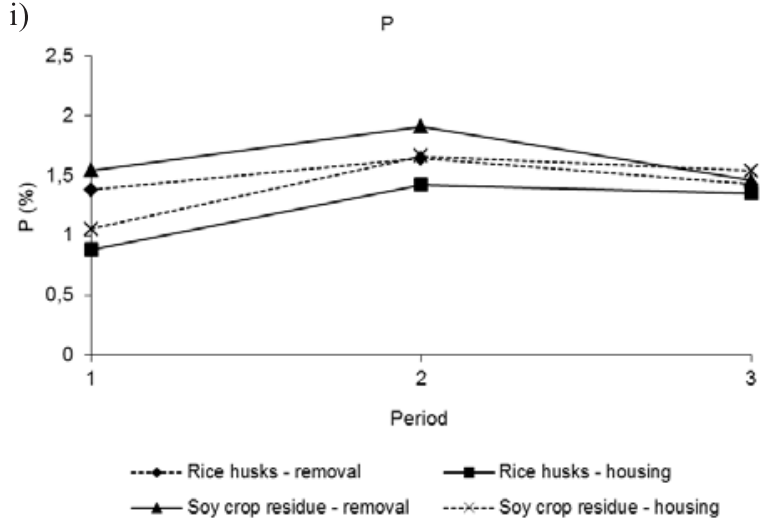

j)

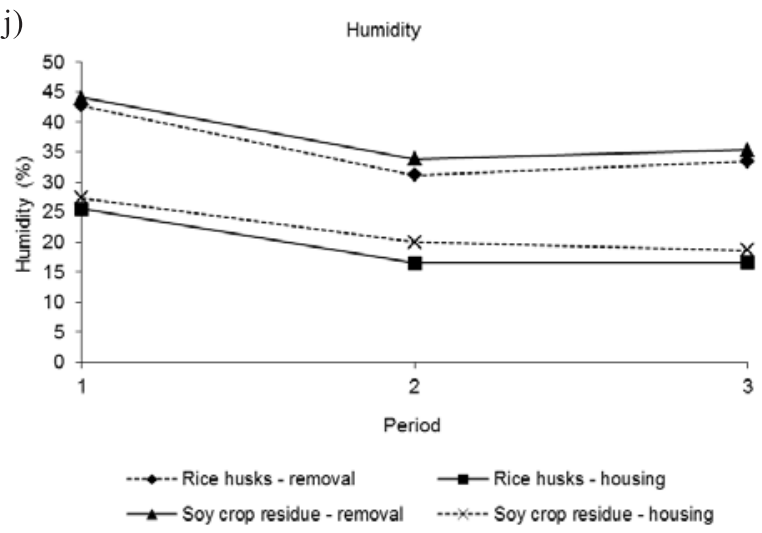

k)

$\mathrm{Zn}$

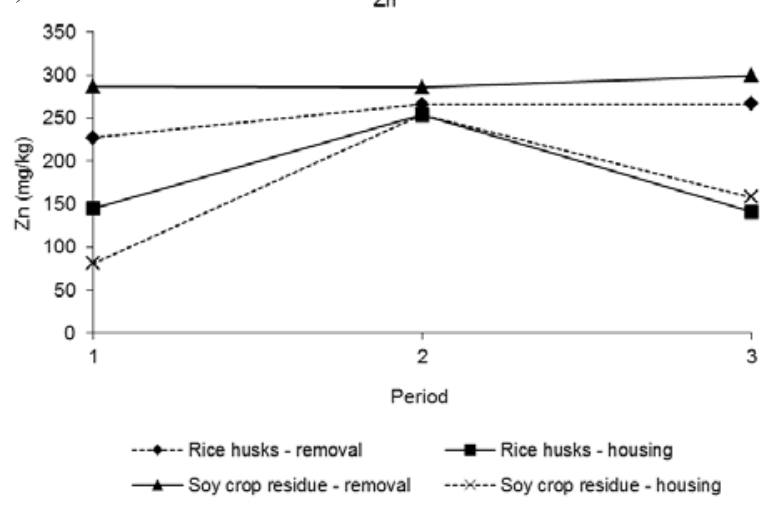

Figure 1 - Chemical composition of broiler litter made with rice husks and soybean straw at flock removal and housing

An exception was $\mathrm{pH}$, which was higher at the end of downtime. Humidity values at flock removal were high, exceeding the recommendations both for poultry rearing and for organic fertilizer; however, at the end of downtime, values returned to acceptable levels. Coufal et al. (2006) observed that the moisture of rice husks litter varied from 23.4 to $29.1 \%$, averaging $26.4 \%$. Those authors found that litter $\mathrm{pH}$ increased from 7.05 to 8.59 after the first flock, and significantly increased between the first and the second flock, after which only minor changes were observed, with an average litter $\mathrm{pH}$ of 8.80 after 18 flocks. Similar $\mathrm{pH}$ values were obtained by Moore Jr. et al. (1996) for rice husks litter reused by four flocks ( $\mathrm{pH}$ 8.75); by Singh et al. (2004), with pH values of 8.4-8.5; and by Ávila et al. (2008), with an average $\mathrm{pH}$ of 8.79. For soybean straw, Ávila et al. (2008) obtained an average $\mathrm{pH}$ of 8.97 .

Ammonia and nitrates are the most common chemical forms of nitrogen found in poultry waste. Nitrates can significantly contaminate underground water when excessive levels of broiler litter are used as crop fertilizer (Oviedo-Rondón, 2008). Moreover, according to that author, phosphorus is found in large amounts in poultry excreta, and its excessive application for crop fertilization may exceed soil and plant capacity to use that nutrient, resulting in leaching and subsequent contamination of underground waters. Ávila et al. (2008) studied six different litter materials reused for six consecutive flocks and found nitrogen values of 2.46 and 2.63 and 0.84 and 1.00 of phosphorus in rice husks and soybean straw, respectively. Coufal et al. (2006) showed that nitrogen, phosphorus, and potassium contents significantly increased in the first seven to eight flocks. Nitrogen, phosphorus, and potassium values obtained in the litter of the fourth flock of the study of Coufal et al. (2006) were $3.56,1.59$, and $3.12 \%$, respectively, and they are used for the comparison with those obtained in the present study.

There is little information on copper ( $\mathrm{Cu}$ ), iron (Fe), zinc $(\mathrm{Zn})$, and manganese (Mn) levels in different poultry litter materials. According to Oviedo-Rondon (2008), poultry feeds are rich in iron, and high levels of this mineral are commonly found in broiler litter. Excessive levels of those mineral in the soil affect plant root growth. That author presented a table with findings of several authors relative to the levels of those trace minerals in poultry litter, and 
those values (in $\mathrm{mg} / \mathrm{kg}$, dry weight) are used to compare with the results of the present study. That table presents average concentrations and ranges of 77 and 58-100 for copper, 1,625 and 1,026-2,288 for iron, 348 and 125-667 for manganese, and finally 315 and 106-669 for zinc.

It must also be mentioned that the chemical characteristics of the litter materials after three flocks comply, in terms of their nutritional aspects, with the legislation relative to simple organic fertilizer. However, it is recommended that the litter removed from the poultry house is distributed in rows for an additional composting period in order to eliminate or reduce health risks. Despite the effect of litter material on the evaluated parameters, with higher averages promoted by soybean straw, litter made of these crop residues were similar and presented similar characteristics to those described in literature for wood shavings (Turazi et al., 2006), showing that after three flocks, the materials presented excellent fertilizing characteristics.

Regarded to physical aspects, when the first flock was removed, soybean straw litter was more compacted and caked when compared to rice husks litter, and this condition remained for the following three flocks, requiring labor interference to break the caked parts, inclusively during the rearing period. At flock removal, soybean straw required more labor to allow its reuse due to the formation of a caked layer on the top of the litter. When the fourth and last flock was removed, the litter made with soybean straw had reached its maximum limit of reutilization, with decomposition of the lower layer, presenting fiber breakdown and wet matter formation. Rice husks litter, on the other hand, presented reuse conditions after the removal of the fourth flock.

Pinto et al. (2005) recommended monitoring insect populations in poultry houses as a routine procedure of the management program, regardless to the strategy used for insect control. However, according to Godinho \& Alves (2009), it is difficult to carry out darkling beetle population studies because their population is usually very high in poultry houses, and they have cryptic behavior.

In the present study, one of its objectives was to know which litter material was more favorable to the dissemination of darkling beetles, as well as the evolution of this population as the litter was reused by several consecutive flocks. Darkling beetle count was significantly influenced $(\mathrm{p}<0.05)$ by litter material, flock, and the interactions between litter material and ventilation and between litter material and flock (Table 4).

Rice husks presented lower darkling beetle count $(\mathrm{p}<0.05)$ as compared to soybean straw, with oscillating ventilation in all flocks, and after the second flock, with stationary ventilation (Figure 2). Darkling beetle count increased from the first to the third flock, and decreased in the fourth flock, independently of litter material or ventilation. Uemura et al. (2008), studying darkling beetle distribution and population dynamics, observed that in broiler houses with cement floor covered with wood shavings litter reused for four flocks and equipped with automatic feeders, the average numbers of insects trapped in the first flock were 385.4 larvae and 24.5 adults, and these figures increased to 615.3 larvae and 208.7 adults in the next flock. Those authors found that the population tended to become stable in the third flock (651.3 larvae and 248 adults), and found an apparent reduction to 422 larvae and 160.2 adults per trap in the fourth flock. They also found that average litter temperature in flock 1 was $30.7^{\circ} \mathrm{C}$, which favors the multiplication of saprophyte microorganisms.

Air and litter temperatures directly influence the population of darkling beetles (Chernaki \& Almeida, 2001): temperatures of 22 and $31^{\circ} \mathrm{C}$ determine incubation periods of 8.9 and 3 days, respectively. Below $17^{\circ} \mathrm{C}$, eggs do not hatch. The larval stage can take 70.1 days when environmental temperature is $22^{\circ} \mathrm{C}$ or 33.2 days at $28^{\circ} \mathrm{C}$,

Table 4 - Descriptive probability levels of the $F$ test of the analysis of variance for darkling beetle count transformed into $\log (\mathrm{y}+1)$

\begin{tabular}{lcr}
\hline Causes of variation & DF & P value \\
\hline Litter material & 1 & $<0.0001$ \\
Ventilation & 1 & 0.9873 \\
Litter material $\times$ ventilation & 1 & 0.0185 \\
Flock & 3 & $<0.0001$ \\
Litter material $\times$ flock & 3 & $<0.0001$ \\
Ventilation $\times$ flock & 3 & 0.1792 \\
Litter material $\times$ ventilation $\times$ flock & 3 & 0.3500 \\
\hline
\end{tabular}

DF - degrees of freedom.

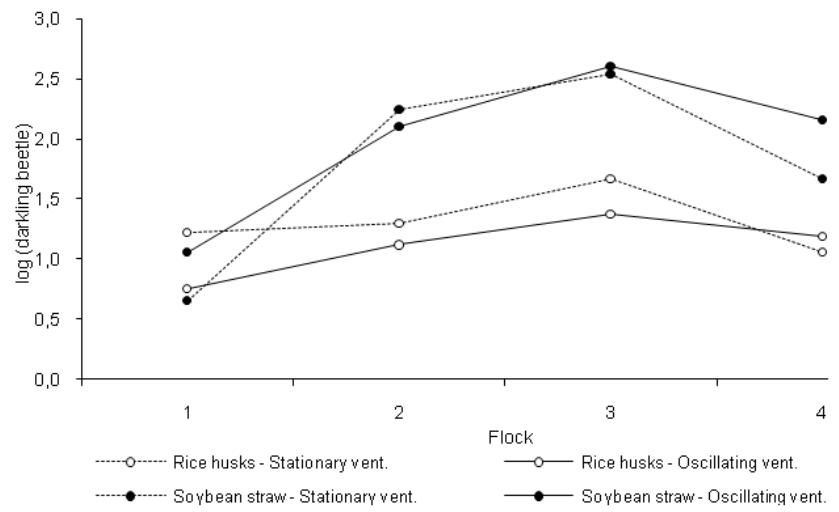

Figure 2 - Average darkling beetle counts, transformed into $\log (y+1)$, in the litter of broilers reared on two different litter materials and under two ventilation systems. 
whereas the pupa stage lasts 4 days at $31^{\circ} \mathrm{C}$ and 9.7 days at $22^{\circ} \mathrm{C}$. Therefore, according those authors, the complete life cycle of the darkling beetle at a constant temperature of $28^{\circ} \mathrm{C}$ is 42.5 days, and considering that a new flock is housed every 50 days, a new generation of darkling beetles may occur at each flock housed in the farm.

In the present study, average air and litter temperatures were mild (Table 6), but they allowed the multiplication of darkling beetles. When the presence of parasites was investigated, only Eimeria sp. occysts were identified, and significant effects $(\mathrm{p}<0.05)$ of litter material and of the interaction between litter material and ventilation on the presence of oocystes were determined. Rice husks submitted to oscillating ventilation presented the higher percentage of contaminated pens and 18.78 more chances of being contaminated as compared to soybean straw submitted to the same ventilation (Table 5). When ventilation was stationary, no differences between litter materials were observed.

When comparing ventilation types, it was found that rice husks litter contamination was significantly higher when ventilation was oscillating (odds ratio $=7.22$ ), whereas there was no significant influence of ventilation type ( $\mathrm{p}>0.05$ ) on the contamination of soybean straw by Eimeiria spp. Other factors may have influenced litter contamination, such as the higher nutrient levels particularly nitrogen levels - in soybean straw, explaining the lower oocyst count due to the negative effects of the release of ammonia levels that are lethal to oocysts (Shirley et al., 1994).

When optimal Eimeria spp oocyst sporulation, which makes it infective, occurs at temperatures of 28 to $30^{\circ} \mathrm{C}$ (Shirley et al., 1994), data were tested to verify if oocyst counts could have changed with litter temperature variations (Table 6), but the results showed that litter temperature did not have any significant influence on oocyst counts.

Table 5 - Percentage of pens contaminated with Eimeiria spp and odds ratio (probability) of being contaminated

\begin{tabular}{lcccc}
\hline Litter material & \multicolumn{2}{c}{ Ventilation } & Odd ratio & $\mathrm{P}>\chi^{2}$ \\
\cline { 2 - 3 } & Oscillating & Stationary & & \\
\hline Rice husks & $81.3 \%$ & $37.5 \%$ & 7.22 & 0.0163 \\
Soybean straw & $18.8 \%$ & $31.3 \%$ & 0.50 & 0.4182 \\
Odds ratio & 18.78 & 1.32 & & \\
$\mathrm{P}>\chi^{2}$ & 0.0012 & 0.7100 & & \\
\hline
\end{tabular}

Table 6 - Means and standard error of the parameters air temperature $\left({ }^{\circ} \mathrm{C}\right)$ and litter temperature $\left({ }^{\circ} \mathrm{C}\right)$ as a function of week and time measurements

\begin{tabular}{|c|c|c|c|c|}
\hline \multirow[t]{2}{*}{ Hour } & \multicolumn{4}{|c|}{ Week } \\
\hline & 4 & 5 & 6 & Mean \\
\hline & \multicolumn{4}{|c|}{ Air temperature $\left({ }^{\circ} \mathrm{C}\right)$} \\
\hline 8:00 a.m. & $16.15 \pm 0.45$ & $13.03 \pm 0.47$ & $15.93 \pm 0.59$ & $15.04 \pm 0.30$ \\
\hline 11:00 a.m. & $19.86 \pm 0.48$ & $17.08 \pm 0.51$ & $21.10 \pm 0.63$ & $19.34 \pm 0.33$ \\
\hline 2:00 p.m. & $24.30 \pm 0.49$ & $21.14 \pm 0.52$ & $25.93 \pm 0.65$ & $23.79 \pm 0.33$ \\
\hline \multirow[t]{2}{*}{ 5:00 p.m. } & $23.23 \pm 0.39$ & $20.64 \pm 0.41$ & $24.97 \pm 0.52$ & $22.95 \pm 0.27$ \\
\hline & \multicolumn{4}{|c|}{ Litter temperature $\left({ }^{\circ} \mathrm{C}\right)$} \\
\hline 8:00 a.m. & $17.12 \pm 0.36$ & $14.86 \pm 0.50$ & $19.77 \pm 0.51$ & $17.25 \pm 0.27$ \\
\hline 11:00 a.m. & $20.87 \pm 0.38$ & $19.39 \pm 0.53$ & $24.12 \pm 0.54$ & $21.46 \pm 0.28$ \\
\hline 2:00 p.m. & $24.35 \pm 0.37$ & $23.48 \pm 0.51$ & $27.71 \pm 0.52$ & $25.18 \pm 0.27$ \\
\hline 5:00 p.m. & $24.20 \pm 0.27$ & $22.84 \pm 0.38$ & $27.53 \pm 0.38$ & $24.86 \pm 0.20$ \\
\hline
\end{tabular}

Means followed by different letters in the same column are different $(\mathrm{p} \leq 0.05)$ by $\mathrm{F}$ test.

\section{Conclusions}

Broiler litter used for three flocks usually complies with the minimal legal requirements to be traded as simple organic fertilizer, independently from the material. Soybean straw can be used as litter for rearing up to four flocks of broilers. At this same number of flocks, rice husks remain usable, whereas soybean straw is deteriorated under humification. The number of darkling beetles is higher in the soybean straw litter and the rice husks litter present 18.78 more chances of being contaminated with oocysts when ventilation is oscillating when compared to soybean straw litter.

\section{Acknowledgements}

The authors thank Fundação de Apoio à Pesquisa de Santa Catarina - FAPESC, for funding this study, Unifrango Agroindustrial de Alimentos Ltda., in the person of the farmer Mr. Arsênio for supplying the litter material, and Roster Ind. e Com. Ltda for lending the fans. 


\section{References}

ANGELO, J.C.; GONZALES, E.; KONDO, N. et al. Litter material: qualidade, quantidade and efeito sobre o desempenho de frangos de corte. Revista Brasileira de Zootecnia, v.26, n.1, p.121-130, 1997.

ARAÚJO, J.C.; OliVeiRA, V.; BRAGA, G.C. Desempenho de frangos de corte criados em diferentes tipos de cama and taxa de lotação. Ciência Animal Brasileira, v.8, n.1, p.59-64, 2007.

ARENDS, J.J. Control, management of the litter beetle. Poultry Digest, v.46, n.542, p.172-176, 1987.

ARENDS, J.J. External parasites and poultry pests. In: CALNEK, B.W. (Ed.) Diseases of poultry. 9.ed. Ames: Iowa State Univ. Press, 1991. p.703-730 (710-712).

ATAPATTU, N.S.B.M.; WICKRAMASINGHE, K.P. The use of refused tea as litter material for broiler chickens. Poultry Science, v.86, n.5, p.968-972, 2007.

AVILA, V.S.; OLIVEIRA, U.; FIGUEIREDO, E.A.P. et al. Avaliação de materiais alternativos em substituição à maravalha como cama de house. Revista Brasileira de Zootecnia, v.37, p.273-277, 2008.

BENABDELJELIL, K.; AYACHI, A. Evaluation of alternative litter materials for poultry. Journal Applied Poultry Science, v.5, p.203-209, 1996.

BRASIL. Ministério da Agricultura, Pecuária and Abastecimento (MAPA) Manual de métodos analíticos oficiais para fertilizantes minerais, orgânicos, organominerais and corretivos. Disponível em: <http://www.agricultura.gov.br>. Acesso em: 23/10/2007.

CHERNAKI-LEFFER, A.M.; BIESDORF, S.M.; ALMEIDA, L.M. et al. Isolamento de enterobactérias em Alphitobius diaperinus and na cama de aviários no oeste do Estado do Paraná, Brasil. Revista Brasileira de Ciência Avícola/Brazilian Journal of Poultry Science, v.4, n.3, p.243-247, 2002.

CHERNAKI, A.M; ALMEIDA, L.M. Exigências térmicas, period de desenvolvimento and sobrevivência de imaturos de Alphitobius diaperinus (Panzer) (Coleoptera: Tenebrionidae). Neotropical Entomology, v.30, n.3, p.365-8, 2001

COUFAL,C.D.; CHAVEZ, C.; NIEMEYER, P.R. et al. Effect of top-dressing recycled broiler litter on litter production, litter characteristic, and nitrogen mass balance. Poultry Science, v. 85, p.392-397, 2006.

GODINHO, R.P.; ALVES, L.F.A. Método de avaliação de população de cascudinho (Alphitobius diaperinus) panzer em aviários de frango de corte. Arquivos do Instituto Biológico, v.76, n.1, p.107-110, 2009.

MIZUBUTI, I.Y.; FONSECA, N.A.N.; PINHEIRO, J.W. Desempenho de duas linhagens comerciais de frangos de corte, criadas sob diferentes densidades populacionais and diferentes tipos de camas. Revista da Sociedade Brasileira de Zootecnia, v.23, n.3, p.476-484, 1994.

MOORE JUNIOR, P.A.; DANIEL, T.C; EDUARDS, D.R. et al. Evaluation of chemical amendments to reduce ammonia volatilization from poultry litter. Poultry Science, v.75, p.315-320, 1996.

MOUCHREK, E.; LINHARES, F.; MOULIN, C.H.S. et al. Identificação de materiais de cama de frango de corte criados em diferentes densidades na época fria. In: REUNIÃO ANUAL DA SOCIEDADE BRASILEIRA DE ZOOTECNIA, 29, 1992, Lavras. Anais... Lavras: SBZ, 1992. p.344.

OLIVEIRA, M.C.; CARVALHO, I.D. Rendimento and lesões em carcaça de frangos de corte criados em diferentes camas and densidades populacionais. Ciência and Agrotecnologia, v.26, n.5, p.1076-1081, 2002.
OVIEDO-RONDÓN, E.O. Tecnologias para mitigar o impacto ambiental da produção de frangos de corte. Revista Brasileira de Zootecnia, v.37, suplemento especial, p.239-252, 2008.

PINTO, D.M.; RIBEIRO, P.B.; BERNARDI, E. Flutuação populacional de Alphitobius diaperinus (Panzer, 1879) (Coleoptera: Tenebrionidae), capturados por armadilha do tipo sanduíche, em granja avícola, no Município de Pelotas, RS Arquivos do Instituto Biológico, v.72, n.2, p.199-203, 2005.

SAFRIT,R. D.; AXTELL, R.C. Evaluations of sampling methods for darkling beetles (Alphitobius diaperinus) in the litter of turkey and broiler houses. Poultry Science, v. 63, p. 2368-2375, 1984.

SALIN, C.; DELETTRE, Y.R.; VERNON, P. Controling the mealworm Alphitobius diaperinus (Coleoptera: Tenebrionidae) in broiler and turkey houses: field trials with a combined inseticide treatment: Insect Growth Regulator an Pyrethroid. Journal of Economic Entomology, v.96, n.1, p.126-130, 2003.

SANTOS, E.C.; TEIXEIRA, A.S.; TORRES, D.M. et al. Avaliação das propriedades de quatro materiais and duas granulometrias de cama sobre o desempenho de frangos de corte. In: REUNIÃO ANUAL DA SOCIEDADE BRASILIERA DE ZOOTECNIA, 37., 2000, Viçosa, MG. Anais... Viçosa, MG: SBZ, 2000. p.257.

SINDICATO NACIONAL DOS FABRICANTES DE RAÇÃO. Compêndio brasileiro de alimentação animal. São Paulo: SINDIRAÇÕES, 1998.

SINGH, A.; BICUDO, J.R.; TINOCO, A.L. et al. Characterization of nutrientes in built-up broiler litter using trench and random walk sampling methods. The Journal of Applied Poultry Research, v.13, p.426-432, 2004.

SHIRLEY, M.W. Epizootiologia. In: SIMPÓSIO INTERNACIONAL SOBRE COCCIDIOSE, 1994, Santos. Anais... Santos: [s.n.], 1994. p.11-22.

STATISTICAL ANALYSIS SYSTEM - SAS. System for Microsoft Windows: release 9.1. Cary, 2002-2003. (CD-ROM).

SURGEONER, G.A.; ROMEL, K. Control of the lesser mealworm in poultry houses (Coleoptera: Tenebrionidae). University of Ghelph. Disponível em: <http://www.uoguelph.ca/pdc/Factsheets/ FactsheetList.html>. Acesso em: 10/11/2005.

TEDESCO, M.J.; GIANELO, C.; BISSANI, C.A. et al. Análise de solo, plantas and outros materiais. 2.ed. Porto Alegre: UFRGS/Dep de Solos, 1995. 174p.

TURAZI, C.M.V.; JUNQUEIRA, A.M.R.; OLIVEIRA, A.S. et al. Horticultura Brasileira, v.24, n.1, p.65-70, 2006.

UEMURA, D.H.; ALVES, L.F.A.; OPAZO, M.U. et al. Distribuição and dinâmica populacional do cascudinho Alphitobius diaperinus (Coleoptera: Tenebrionidae) em aviários de frango de corte. Arquivos do Instituto Biológico, v.75, n.4, p.429-435, 2008.

VITTORI, J.; SCHOCKEN-ITURRINO; R.P.; TROVÓ, K.P. et al. Alphitobius diaperinus como veiculador de Clostridium perfringens em granjas avícolas do interior paulista-Brasil. Ciência Rural, v.37, n.3, p.894-896, 2007.

WATSON, D.W.; DENNING, S.S.; ZUREK, L. et al. Effects of lime hidrated on the growth and development of darkling beetle, Alphitobius diaperinus. International Journal of Poultry Science, v.2, n.2, p.91-96, 2003.

WILLIS, W.L.; MURRAY, C.; TALBOTT, C. Evaluation of leaves as a litter material. Poultry Science, v.76, p.1138-1140, 1997.

WINDHAM, W.R. (Ed.) Animal feed. In: CUNNIFF, P. (Ed.) Official methods of analysis of AOAC International. 16.ed. Arlington: AOAC International, 1995. v.1, cap. 4, p.1, 4, 27 (Method 965.17).

XAVIER, L.H. Modelos univariado e multivariado para análise de medidas repetidas e verificação da acurácia do modelo univariado por meio de simulação. 91f. 2000. Dissertação (Mestrado em Agronomia) - Escola Superior de Agricultura "Luiz de Queiroz”, Piracicaba. 